\title{
Factors Related to Behavior the Community in Disposing of Garbage
}

\author{
Nor Wijayanti \\ Institute of Health Science Surya Global Yogyakarta, Indonesia \\ Corresponding author email: wijayantinor@gmail.com
}

\begin{abstract}
According to the American Public Health Association, junk is defined as something that is not used, unused, unwanted, or something disposed of, derived from human activities, and does not happen by itself. Based on data from the Department of Environment Bantul Regency Year Of 2018 Producing the biggest waste there is in the District of Banguntapan Yogyakarta by 264,49 m3/day while the lowest was 77,64 m3/daycare in the District of Kretek Yogyakarta. The results of the interviews in the community was found that as much as $45 \%$ of citizens have yet to separate or distinguish organic and inorganic waste. The purpose of this study was to determine the factors associated with the behavior of the community in disposing of garbage in the Village. This research uses descriptive quantitative with a cross-sectional approach. The sampling technique used is accidental sampling with a total sample of 76 respondents. The analysis used is the analysis of univariate and bivariate with Chi-Square statistical test. The results of this research are on the analysis of the chi-square showed no relationship between the factors with the behavior of the community in disposing of garbage as follows education with behavior sig. 0,002 ( $p<0,05)$, the income with the behavior of the sig. 0,037 ( $p<0.05)$, availability of infrastructure is. $0.000(p<0.05)$. The conclusion obtained that there is a significant relationship between educations, income, and availability of infrastructure to the behavior of the community in disposing of garbage in the Village of Banguntapan Yogyakarta.

Keywords---behavior, garbage education, income, infrastructure.
\end{abstract}

\section{Introduction}

According to the American Public Health Association, garbage (waste) is defined as something that is not used, unused, unwanted, or discarded, derived from human activities, and does not occur by itself (Sumanrti, A, 2017). According to Law No. 18 of 2008 on Waste Management, the waste must be managed with the appropriate method and engineering waste management which is environmentally friendly so as not to harm health. Producer of the biggest waste in the district of Banguntapan by $264,49 \mathrm{~m} 3 /$ day while the lowest was $77,64 \mathrm{~m} 3 /$ day is in the district of Kretek. The high waste generation is caused by several factors, among others, high population density and increased activity, as well as not all parties, have the ability and willingness to manage trash with the $3 \mathrm{R}$ principle (Reduce, Reuse, Recycle).

The Volume of waste handled in 2017, the Processing of waste in the District of Bantul implemented with the principle of reducing, utilize, and recycle garbage, employing local, communal, and waste processing independently. Processing of waste in a landfill temporarily set up scattered all over the district following the level of service. The Final Disposal waste that in the district of Piyungan area of approximately 12 hectares, which is managed by the sanitary landfill for the residual waste end. Trash service centralized large enough to be in the region of the district which belongs to the urban area of the District of Bantul Banguntapan, Sewon, and Pity. While the district of Dlingo completely unserved by the trash service is centralized. Based on total volume transported, the volume of waste smallest garbage from the landfills market. The results of preliminary studies conducted on October 5, 2019, was found that as many as $45 \%$ of residents are not separate or distinguish organic and inorganic. While the trash is there that can be decomposed and difficult to disentangle, lack of knowledge regarding the disposal of waste properly following the type of waste, the availability of facilities and infrastructure such as landfills while still less (The Department Of The Environment, 2018). 
The purpose of this study is as follows: 1) to determine the relationship of level of education, income, availability of facilities, and infrastructure with the behavior of the public in disposing of waste in the Banguntapan Village. 2) to determine the Relationship of the availability of the means with the behavior of the public in disposing of Waste in the Hamlet of Banguntapan Village.

\section{Research Method}

Research is survey research is descriptive quantitative. The research design used was Cross-Sectional (Notoatmodjo, $\mathrm{S}, 2012$ ). The population used in this research is all the head of the family from 8 RT Based on data from the Office of the Village Hall Banguntapan in the research area are 259 Households. Based on the calculation of the sample respondents in the study is adjusted to be as much as $73 \mathrm{HH}$ from the total number of Households per $8 \mathrm{RT}$ is done to simplify the management of data and to the results of the better testing. This research was conducted in the Village Banguntapan District of Bantul the study was conducted for 2 months from December to January 2020.

Collecting data using primary data and secondary data, primary data using questionnaires and observation, and secondary data using the report Village Banguntapan that's already there. The technique of data analysis using univariate and bivariate. Analysis univariate aims to explain or characteristics description each study variable. Form of univariate analysis depending on the type of the data. For data use of numerical value, or average, median, and standard deviation (Chen et al., 2020; Hardy-Smith \& Edwards, 2004; Hayden \& Cannon, 1983). In general, this analysis only generates a frequency distribution and a percentage of each variable. Bivariate analysis, if it has been performed univariate analysis to the above, the result will be aware of the characteristics of the distribution of each variable and can be continued bivariate analysis. Bivariate analysis was done against two variables that are allegedly associated or correlated.

\section{Result}

Results on the univariate analysis found the characteristics of the respondents as Table 1.

Table 1

Frequency Distribution Characteristics of the Respondents in the Banguntapan Village

\begin{tabular}{lll}
\hline Characteristics of the Respondents & Frequency & Percentage \% \\
\hline Age & & \\
$\leq 29$ years old & 3 & 3.9 \\
30-39 years old & 7 & 9.2 \\
40-49 years old & 23 & 30.3 \\
$\geq 49$ years old & 43 & 56.6 \\
\hline Gender & & \\
Male & 52 & 68.4 \\
Female & 24 & 31.6 \\
\hline Total & 76 & 100.0 \\
\hline \hline
\end{tabular}

Table 1 shows that most of the respondents aged > 49 Years that a number of the 43 respondents $(56.6 \%)$. Respondents are aged 40-49 Years, 23 respondents (30.3\%). Respondents aged 30-39 Years while 7 respondents $(9.2 \%)$. While the remainder is 3 respondents $(3.9 \%)$ with age <29 Years. And most of the male respondents $(68.4 \%)$. While the rest of the female respondents, namely 24 respondents $(31.6 \%)$.

Table 2

The Frequency Distribution of the Study Variables in the Banguntapan Village

\begin{tabular}{lll}
\hline Research Variable & Frequency & Percentage \% \\
\hline Education & 20 & 26.3 \\
Low & 35 & 46.1 \\
Medium & 21 & 27.6 \\
\hline
\end{tabular}




\begin{tabular}{lcc}
\hline Income & & \\
\hline Under minimum wage work & 39 & 51.3 \\
Above minimum wage work & 37 & 48.7 \\
\hline Availability of infrastructure & & \\
\hline Available & 38 & 50.0 \\
Nor available & 38 & 50.0 \\
\hline The behavior of public figures & & \\
\hline Good & 41 & 53.9 \\
Not good & 35 & 46.1 \\
\hline Total & 76 & 100.0 \\
\hline
\end{tabular}

Table 2 shows that the education of the majority of respondents with secondary education level as much as 35 people $(46.1 \%)$, respondents who have higher education level as many as 21 people $(27.6 \%)$, and respondents with low education as many as 20 people $(26.3 \%)$. The majority of the income level of the respondents, namely under the MSE (Minimum Wage Work) as much as 39 people (51.3\%), and income at the top of the MSE (Minimum Wage Work) as much as 37 people (48.7\%). The majority of the availability of the infrastructure of the respondents with the available means of as much as 38 people $(50.0 \%)$ and there are no available means of respondents as many as 38 people $(50.0 \%)$. The majority of the behavior of public figures with good behavior as much as 41 people (53.9\%) and the behavior of public figures with the behavior is not good as many as 35 people (46.1\%).

The results of bivariate analysis

Table 3

Cross-Tabulation Factors Associated with the Behavior of the Public in Disposing of Waste

\begin{tabular}{|c|c|c|c|c|c|c|c|c|}
\hline \multirow{3}{*}{ Factors Associated } & \multicolumn{4}{|c|}{ The behavior of littering } & \multirow{2}{*}{\multicolumn{2}{|c|}{ Number }} & \multirow{3}{*}{ P-Value } & \multirow{3}{*}{ OR } \\
\hline & \multicolumn{2}{|c|}{ Not good } & \multicolumn{2}{|c|}{ Good } & & & & \\
\hline & $\mathrm{F}$ & $\%$ & $\mathrm{~F}$ & $\%$ & $\mathrm{~F}$ & $\%$ & & \\
\hline Income & & & & & & & & \\
\hline Under Mininum wage work & 23 & 59 & 16 & 41.0 & 39 & 100 & 0.037 & 2,995 \\
\hline Above Mininum wage work & 12 & 32,4 & 25 & 67.6 & 37 & 100 & & \\
\hline Total & 35 & 46,1 & 41 & 53,9 & 76 & 100 & & \\
\hline Education & & & & & & & & \\
\hline Low & 16 & 80.0 & 4 & 20.0 & 20 & 100 & 000 & \\
\hline Medium & 12 & 34,3 & 23 & 65,7 & 35 & 100 & 0,002 & \\
\hline High & 7 & 33,3 & 14 & 66,7 & 21 & 100 & & \\
\hline Total & 35 & 46,1 & 41 & 53,9 & 76 & 100 & & \\
\hline Availability Of & & & & & & & & \\
\hline $\begin{array}{l}\text { Infrastructure } \\
\text { Not Available }\end{array}$ & 26 & 68,4 & 12 & 31.6 & 38 & 100 & 0.000 & 6,981 \\
\hline Available & 9 & 23,7 & 29 & 76,3 & 38 & 100 & & \\
\hline Total & 35 & 46,1 & 41 & 53,9 & 76 & 100 & & \\
\hline
\end{tabular}

Table 3 on the education variable obtained results of Chi-Square with a significant level of 5\% obtained p-value of 0.002 , so the p-value is $<0.05$ then Ho is rejected and Ha accepted which means that there is a relationship between education with the behavior of littering in the Banguntapan Village District of Bantul, and the level of education of the medium as much as 35 respondents (100\%) a total of 23 respondents $(65.7 \%)$ had good behavior, while 12 respondents $(34.3 \%)$ had behavior is not good. Of the 21 respondents $(100 \%)$ who were highly educated, as many as 14 people respondents $(66.7 \%)$ behave better, and 7 people respondents $(33.3 \%)$ behave no better. Whereas of the 20 respondents $(100 \%)$ who are poorly educated, there are 4 respondents $(20.0 \%)$ who had good behavior and 16 respondents $(80.0 \%)$ have behavior is not well in disposing of waste. The results of the research found no relationship between education with the behavior of littering.

On a variable income obtained results of Chi-Square with a significant level of 5\% obtained p-value of 0.020 so that the p-value is $<0.05$ then Ho is rejected and Ha accepted which means that there is a relationship between 
income and the behavior of littering in the Banguntapan Village District of Bantul, and obtained the value of OR= 2,995 that the respondents had income levels below the MSE then have a great chance to 2.9 times more likely to behave better in disposing of waste compared with respondents who have income levels above the MSE with good behavior in the garbage. of the 39 respondents (100\%) income under the MSE (Minimum Wage Work), there are 23 respondents $(59.0 \%)$ who do not behave well in disposing of waste, and as many as 16 respondents (41.0\%) had good behavior in disposing of waste. While the 37 respondents (100\%) income above UMK (Minumum Wage Job), there are 12 respondents (32.4\%) who do not behave well in disposing of waste, and 25 respondents (67.6\%) had good behavior in disposing of waste.

In the variable availability of infrastructure obtained results of Chi-Square with a significant level of $5 \%$ obtained p-value of 0.000 , so the p-value is $<0.05$ then Ho is rejected and Ha accepted which means that there is a relationship between the Availability of infrastructure with the behavior of littering in the Banguntapan Village District of Bantul, and obtained the value of $\mathrm{OR}=6,981$ that respondents who have the availability of means have great opportunities to 6.9 times more likely to behave better in throw the trash compared to respondents who do not have the availability of means. most respondents the availability of infrastructure as much as 38 respondents (100\%), 29 respondents $(76.3 \%)$ had good behavior, 9 respondents $(23.7 \%)$ have behavior is not good. While that is not available infrastructure as much as 12 respondents (31.6\%) had good behavior, and 26 respondents (68.4\%) had behavior is not good. This means that in the absence of the availability of the means then it can affect the action of dumping of waste is not good.

\section{Discussion}

Table 3 shows the results of the relationship of income with the behavior of the community values obtained OR= 2,995 that the respondents had income levels below the MSE then have a great chance to 2.9 times more likely to behave better in disposing of waste compared with respondents who have income levels above the MSE with good behavior in the garbage. Someone who has higher incomes has more opportunity to buy equipment place garbage disposal and procurement of place management, compared with someone who has an income below the average, and if the means of the bins are met then the most likely state of the environment clean (Safitri, 2018; Takaku et al., 2006).

Respondents 20 people who have already studied (100\%) who are poorly educated, there are 4 respondents (20.0\%) who had good behavior and 16 respondents $(80.0 \%)$ have behavior is not well in disposing of waste. According to Nursalam (2011) stated that the higher one's education, the more and more receptive to information so that the more knowledge (Fatimah, 2018). this is in line with research Safitri (2018), education as a factor determining the way of thinking and understanding in the conduct of elections trash. So people who are poorly educated most do not think about how to choose garbage properly and correctly because it does not understand the benefit that is produced after going through a selection of trash. The higher the education the higher the person's knowledge. As well as the higher education and knowledge of someone then it is likely to have good behavior is also great (Safitri, 2017).

Table 3 shows the results of the relationship of income with the behavior of the community values obtained OR= 24,278 that respondents who know are not good then have a great chance of 24.2 times more likely to behave better in throw the trash compared to respondents who have good knowledge.

According to Notoatmodjo (2014), knowledge is the result of 'know', and this happened after people perform sensing on a particular object. Sensing occurs through the five senses of man, namely: the sense of sight, hearing, smell, taste, and conjecture. Most of the human knowledge is acquired from the eyes and ears (Notoatmodjo, S, 2014). The factors that affect the level of knowledge according to Notoatmodjo (2010), namely the level of education, education is an attempt to provide knowledge so that changes in the behavior of the positive increase. Knowledge needs to be improved for the disposal of the household waste following what is expected that eligible health, increase knowledge can be in the form of counseling and provide information associated with the garbage disposal, the more variety the source of information or counseling obtained by a person the better the knowledge of the person (Notoatmojo S, 2010). The results of this study following the opinion delivered Napis alfikri (2017) that, most of the respondents are already doing garbage disposal better, this happens because most of them got information from friends, health workers, about to throw the garbage, while many of them do not know the information dispose of waste because of the lack of looking for information related to the health of the environment so that their understanding of the trash is still lacking. This is what makes them do the garbage disposal is not good (Napis Alfikri, 2017). This is in line with research Resting Restiawati (2018) said the strong relationship of knowledge with the behavior of littering because knowledge is the basis for a person to behave, it shows that 
knowledge is a factor that needs to be considered and be a priority to change the behavior of the public in disposing of waste, from the discussion it can be concluded that the better the knowledge of the respondents then tend to his behavior in the garbage disposal, the better and conversely the less knowledge then it is less likely the behavior in the garbage disposal (Resting Restiwati, 2018).

The results of the research can be known that most of the respondents had a good attitude that most of them agree on the processing of waste separated before being discharged, the good attitude also influenced by the knowledge that so well that encourage a person to be positive about what they already know. The results of the relationship of the availability of advice infrastructures with the behavior of the community values obtained $\mathrm{OR}=6,981$ that respondents who do not have the availability of means have great opportunities to 6.9 times more likely to behave better in disposing of garbage compared to the respondents who have the availability of means (Kinnaman \& Fullerton, 2000; Nursalam, 2011). Based on Law No. 18 of 2008 states that any person is entitled to receive services in terms of waste management in the local government, or other parties who are given the responsibility in the management of waste and landfills. Each local government has the task of carrying out waste management and facilitate the provision of infrastructure and waste management (Republic act No 18 , 2008).

In line with the research Nafis Alfikri (2017), stated that the more complete the facilities and the means available then will be the better practices and behavior in terms of taking out the garbage. How most are not owned by the respondent is a trash can that has a lid, the lack of landfills making it difficult for people to throw garbage and if the availability of means of it will be the better practices and behavior in terms of taking out the garbage. So people will not be littering if the availability a lot of trash (Napis Alfikri, 2017). The results of research following the opinion delivered Resting (2018), because the behavior is not only caused by the availability of landfills while, but things like a lack of awareness in disposing of waste, lack of awareness replenish the provision of garbage disposal in the house and outside the house (Resting Restiwati, 2018).

\section{Conclusion}

Based on the results of analysis and discussion that has been presented by the researchers so in this study can be concluded as follows: 1) There is a relationship between education with the behavior of the public in disposing of waste in the Banguntapan Village. 2) There is a relationship between income and the behavior of the public in disposing of waste. 3) There is a relationship between the availability of infrastructure with the behavior of the public in disposing of waste in the Banguntapan Village.

\section{Acknowledgments}

We thank the Institute of Health Science Surya Global Yogyakarta for the support and assistance provided during our research and special appreciation to all study participants who volunteered for this research.

\section{References}

Chen, S., Huang, J., Xiao, T., Gao, J., Bai, J., Luo, W., \& Dong, B. (2020). Carbon emissions under different domestic waste treatment modes induced by garbage classification: Case study in pilot communities in Shanghai, China. Science of The Total Environment, 717, 137193. https://doi.org/10.1016/j.scitotenv.2020.137193

Fatimah. (2018). Factors Associated With The Behavior of Fruit And Vegetable Consumption In Adolescents In SMP N 3 Banguntapan Yogyakarta. Thesis STIKes Surya Global Yogyakarta.

Hardy-Smith, T., \& Edwards, P. C. (2004). The garbage crisis in prehistory: artefact discard patterns at the Early Natufian site of Wadi Hammeh 27 and the origins of household refuse disposal strategies. Journal of Anthropological Archaeology, 23(3), 253-289. https://doi.org/10.1016/j.jaa.2004.05.001

Hayden, B., \& Cannon, A. (1983). Where the garbage goes: refuse disposal in the Maya Highlands. Journal of anthropological archaeology, 2(2), 117-163. https://doi.org/10.1016/0278-4165(83)90010-7

Kinnaman, T. C., \& Fullerton, D. (2000). Garbage and recycling with endogenous local policy. Journal of Urban Economics, 48(3), 419-442. https://doi.org/10.1006/juec.2000.2174

Napis Alfikri. (2017). The factors Associated With the Act of throwing Garbage In the Environment IV Kelurahan Helvetia Medan. Journal of Sari Mutiara Indonesia University.

Notoatmodjo, S. (2012). Research Methodology Health. Jakarta: PT Rineka Cipta.

Notoatmodjo, S. (2014). Health Science Society And Art. Jakarta: PT Rineka Cipta.

Notoatmojo S. (2010). The science of Health Behavior. Jakarta: PT Rineka Cipta pp. 20, 27-31.

Nursalam, N. (2011). Kebutuhan riil tenaga perawat dengan metode Workload Indicator Staff Need (WISN). Jurnal Ners, 6(1), 85-92. 
Republic act No 18 . (2008). Republic act No 18 of 2008. About Refineries Trash. Jakarta.

Resting Restiwati. (2018). The Factors Associated With The Behavior Of The Disposal Of Household Trash In The Community In The Village Anawai District Wua-Wua Kendari City. Journal of STIKES Mandala Waluya Kendari.

Safitri, D. D. (2018). Managing school based on character building in the context of religious school culture (Case in Indonesia). Journal of Social Studies Education Research, 9(4), 274-294.

Safitri. (2017). The Relationship Of Level Of Education, Knowledge, And Attitudes To The Behavior Of The Waste Management On Traders In Fruit And Vegetable On The Market Giwangan Yogyakarta. Journal of Universitas Ahmad Dahlan.

Sumanrti, A. (2017). The Health Of The Environment. West Java: Kencana.

Takaku, H., Kodaira, S., Kimoto, A., Nashimoto, M., \& Takagi, M. (2006). Microbial communities in the garbage composting with rice hull as an amendment revealed by culture-dependent and-independent approaches. Journal of bioscience and bioengineering, 101(1), 42-50. https://doi.org/10.1263/jbb.101.42

The Department Of The Environment. (2018). Work Information Management Environment Kabupaten Bantul. Yogyakarta. 